University of Nebraska - Lincoln

DigitalCommons@University of Nebraska - Lincoln

Faculty Publications: Department of Entomology

$2-1-2006$

\title{
Evaluation of Cool- and Warm-Season Grasses for Resistance to Multiple Chinch Bug (Hemiptera: Blissidae) Species
}

Wyatt G. Anderson

University of Nebraska-Lincoln

Tiffany Heng-Moss

University of Nebraska-Lincoln, thengmoss2@unl.edu

Frederick P. Baxendale

University of Nebraska-Lincoln, fbaxendale1@unl.edu

Follow this and additional works at: https://digitalcommons.unl.edu/entomologyfacpub

Part of the Entomology Commons

Anderson, Wyatt G.; Heng-Moss, Tiffany; and Baxendale, Frederick P., "Evaluation of Cool- and WarmSeason Grasses for Resistance to Multiple Chinch Bug (Hemiptera: Blissidae) Species" (2006). Faculty Publications: Department of Entomology. 120.

https://digitalcommons.unl.edu/entomologyfacpub/120

This Article is brought to you for free and open access by the Entomology, Department of at DigitalCommons@University of Nebraska - Lincoln. It has been accepted for inclusion in Faculty Publications: Department of Entomology by an authorized administrator of DigitalCommons@University of Nebraska - Lincoln. 


\title{
Evaluation of Cool- and Warm-Season Grasses for Resistance to Multiple Chinch Bug (Hemiptera: Blissidae) Species
}

\author{
WYATT G. ANDERSON, TIFFANY M. HENG-MOSS, AND FREDERICK P. BAXENDALE
}

Department of Entomology, University of Nebraska, Lincoln, NE 68583

\begin{abstract}
J. Econ. Entomol. 99(1): 203-211 (2006)
ABSTRACT Chinch bugs are common pests of many agronomic and horticulturally important crops and turfgrasses. The extensive overlap of plant hosts and geographic distribution of Blissus leucopterus leucopterus (Say), Blissus leucopterus hirtus Montandon, Blissus insularis Barber, and Blissus occiduus Barber underscores the importance of identifying resistant germplasm. Cool- and warm-season turfgrasses and sorghum, Sorghum bicolor (L.) Moench, were evaluated for resistance to chinch bugs in the Blissus complex, and the presence of multiple resistance was documented. Greenhouse studies established that B. occiduus-resistant ('Prestige', formerly NE91-118) and -susceptible (' $378^{\prime}$ ') buffalograsses, , Buchloë dactyloides (Nuttall) Engelmann, were susceptible to all other chinch bug species. KS94 sorghum exhibited resistance to both B. occiduus and B. l. leucopterus, whereas B. insularisresistant St. Augustinegrass, Stenotaphrum secundatum (Walter) Kuntze ('Floratam'), was also resistant to B. occiduus. B. l. leucopterus-susceptible sorghum ('Wheatland') and B. insularis-susceptible St. Augustinegrasses ('Raleigh' and 'Amerishade') were highly resistant to B. occiduus. Endophyte-free and -enhanced fine fescues (Festuca spp.) were moderately to highly susceptible to $B$. l. hirtus but moderately to highly resistant to $\mathrm{B}$. occiduus. The results of this research showed the buffalograsses evaluated, including $B$. occiduus-resistant Prestige, are moderately to highly susceptible to the three other chinch bug species. In contrast, $B$. occiduus did not cause considerable damage to any of the turfgrasses or sorghum cultivars evaluated, other than buffalograss, irrespective of whether or not they are resistant to another chinch bug species. This information is increasingly important as various grasses become adapted to regions that may possess chinch bug species other than those with which they are typically associated. These levels of Blissus resistance should be included when selecting resistant germplasm for managing Blissus species pests.
\end{abstract}

KEY WORDS chinch bug, Blissus, plant resistance, turfgrass, sorghum

Chinch Bugs (Hemiptera: Blissidae: Blissus) are common pests of numerous economically important crops and turfgrasses. In the United States, there are four species that are of major economic importance: the chinch bug, Blissus leucopterus leucopterus (Say); the southern chinch bug, Blissus insularis Barber; the hairy chinch bug, Blissus leucopterus hirtus Montandon; and the western chinch bug, Blissus occiduus Barber (Vittum et al. 1999). Chinch bugs are widely distributed throughout the United States, primarily east of the Rocky Mountains. Individual species often have overlapping geographic distributions. In particular, the geographic distribution of $B$. occiduus, and its preferred host buffalograss, Buchloë dactyloides (Nuttall) Engelmann, are such that any of the other chinch bug species could be present in adjacent turfgrasses, crops, or a combination (Eickhoff et al. 2004). Furthermore, all four chinch bug species have extensive documented host ranges.

The most common hosts of B. l. leucopterus include sorghum, Sorghum bicolor (L.) Moench; corn, Zea mays L.; wheat, Triticum aestivum L.; and many turf- grasses, including Bermuda grass, Cynodon dactylon (L.) Persoon; Kentucky bluegrass, Poa pratensis L.; fescues, Festuca spp.; and zoysiagrass, Zoysia japonica Steudel (Leonard 1966, Reinert et al. 1995).

B. leucopterus hirtus is most commonly associated with northern cool-season turfgrasses, especially fescues; perennial ryegrasses, Lolium perenne L.; and Kentucky bluegrass (Shetlar 2000). In addition, B. $l$. hirtus has been documented feeding on timothy grass, Phleum pratense L.; bentgrass, Agrostis spp.; and warmseason turfgrasses, including zoysiagrass and St. Augustinegrass, Stenotaphrum secundatum (Walter) Kuntze (Vittum et al. 1999).

Although B. insularis is only considered a serious pest of St. Augustinegrass (Kerr 1966, Vittum et al. 1999), it also has been reported on torpedograss, Bermuda grass, bahiagrass, centipedegrass, and zoysiagrass (Vittum et al. 1999).

Finally, the reported hosts of B. occiduus include corn; wheat; barley, Hordeum spp.; sugarcane, Sacharum officinarum L.; brome, Bromus spp.; and more recently, buffalograss and zoysiagrass (Ferris 1920, 
Bird and Mitchener 1950, Farstad and Staff 1951, Baxendale et al. 1999, Eickhoff et al. 2004). In addition, recent research by Eickhoff et al. (2004) documented the potential of $B$. occiduus to use additional turfgrasses, crops, and weeds, including Kentucky bluegrass; perennial ryegrass; tall fescue; Festuca arundinacea Schreber; Bermuda grass; sorghum; yellow foxtail, Setaria glauca (L.); and green foxtail, Setaria viridis (L.), as alternate hosts.

Historically, insecticides have been used as the principle method to control chinch bugs. However, growing concerns over the repeated use of chemicals and the potential negative side effects have led to the development of integrated pest management tactics, including the use of chinch bug-resistant germplasm. Over the past several years, germplasm resistant to each of the four economically important chinch bugs has been identified and integrated into pest management programs.

Chinch Bug Resistance. The use of resistant sorghum crops to manage B. l. leucopterus was investigated by Dahms (1948) who found that the "milos" and "fertitas" are susceptible, and the "kafirs" and "sorgos" exhibit resistance to chinch bug feeding. More recently, Mize and Wilde (1986a, b, c) reported that the sorghum lines 1155, SC 303, SC 261, and BCK601155 displayed high levels of antixenosis and tolerance compared with the resistant 'Atlas' and susceptible 'Wheatland' checks. The experimental sorghum selection KS94 also has been shown to be resistant to the common chinch bug (Wilde and Bramel-Cox 1991). Subsequent research by Subramanian (1995) suggested that KS94 exhibited both tolerance and antixenosis.

It has been well-documented that endophyte-infected turfgrasses exhibit resistance to $B$. $l$. hirtus (Saha et al. 1987, Mathias et al. 1990, Carrière et al. 1998, Richmond and Shetlar 2000, Yue et al. 2000). Saha et al. (1987) first reported reduced numbers of $B$. l. hirtus on fine-leaf fescues infected with endophytes. Mathias et al. (1990) reported endophyte-enhanced perennial ryegrass cultivars to be resistant to $B$. l. hirtus and speculated that both antibiosis and antixenosis were responsible for $B$. l. hirtus resistance in those cultivars. Unfortunately, many of the perennial ryegrass and fine fescue cultivars known to have resistance to $B$. l. hirtus are no longer commercially available.

St. Augustinegrasses with resistance to $B$. insularis also have been identified. 'Floratam' and 'Floralawn' were shown to be resistant to B. insularis, and Floratam was extensively planted in the southern United States (Reinert and Dudeck 1974; Crocker et al. 1982, 1989; Busey and Zaenker 1992). Floratam's resistance to $B$. insularis has been categorized as antibiosis because of high chinch bug mortality and reduced oviposition rates (Reinert and Dudeck 1974, Crocker et al. 1989). However, in parts of southern Florida, biotypes emerged that were able to damage resistant germplasm (Busey and Center 1987). Recent research efforts have identified new sources of St. Augustinegrass resistant to B. insularis, including FX-10, which is thought to be resistant to both B. insularis populations (Busey 1990, 1993, 1995).

Heng-Moss et al. (2002) identified the buffalograsses 'Prestige' (formerly NE91-118), 'Tatanka', 'Bonnie Brae', and 'Cody' as moderately to highly resistant to B. occiduus, whereas the buffalograss selections ' 378 ' and NE84-45-3 were highly susceptible in greenhouse and field studies. Subsequent research demonstrated that Cody and Tatanka exhibited tolerance to B. occiduus, whereas Prestige displayed both tolerance and antixenosis (Heng-Moss et al. 2003). No antibiosis was detected in any of the buffalograsses examined.

Multiple Chinch Bug Resistance. Buffalograss, a native of the central Great Plains, is currently grown in both high and low management sites throughout the United States. Its aggressive stoloniferous growth habit and dense sod-forming capabilities are well suited for turfgrass use and make it an excellent conservation species. Buffalograss stands are usually established through vegetative propagation, which can result in the unintentional movement of $B$. occiduus and other arthropods to new regions in the United States. Indeed, the presence of B. occiduus has been documented in vegetatively propagated stands of buffalograss in Kansas, Iowa, Oklahoma, and Arizona.

Because of the extensive geographical overlap of the four economically important chinch bug species (B. occiduus, B. insularis, B. l. leucopterus, and B. $l$. hirtus) and their host plants, the potential exists for $B$. occiduus and other chinch bug species to become associated with and damage nontraditional hosts. The presence of host plants with resistance to multiple chinch bug species would be highly desirable in these interfacing turfgrass-crop situations. Unfortunately, limited information is available on turfgrass germplasm with resistance to multiple insect species. Funk et al. (1983) reported that an endophyte-enhanced perennial ryegrass, 'Pennant', was less damaged by sod webworms (Crambus spp.) and billbugs (Sphenophorus spp.) than other grasses in field trials. Otherwise, few reports of multiple insect resistance in turfgrasses exists. Although germplasm resistant to each of the four chinch bug species is known, the existence of plants with multiple chinch bug resistance remains uncertain. The objectives of this research were to evaluate selected cool- and warm-season turfgrasses and sorghum for resistance to chinch bugs in the Blissus complex of B. occiduus, B. l. leucopterus, B. l. hirtus, and B. insularis and to document any incidence of multiple resistance.

\section{Materials and Methods}

Acquisition and Maintenance of Chinch Bugs. $B$. occiduus were collected with a modified ECHO Shred 'N Vac (model \#2400, ECHO Incorporated, Lake Zurich, IL) from buffalograss ' 378 ' (chinch bug-susceptible) research plots at the John Seaton Anderson Turfgrass and Ornamental Research Facility (JSA Research Facility), University of Nebraska Agricultural Research and Development Center, near Mead, NE. 
Chinch bugs were held under laboratory conditions $\left(26 \pm 3^{\circ} \mathrm{C}\right.$ and a photoperiod of 16:8 [L:D] h) for $24 \mathrm{~h}$ to eliminate individuals injured or killed during the collection process, sifted through a 2-mm mesh screen, collected with a battery-powered aspirator, and introduced on to experimental plants.

B. l. leucopterus were collected from infested sorghum at the JSA Research Facility by placing infested plants in plastic bags or by using a modified ECHO Shred ' $N$ Vac to vacuum chinch bugs and plant debris. Collected chinch bugs were processed as described for B. occiduus.

B. l. hirtus were collected from infested Kentucky bluegrass lawns near Columbus, $\mathrm{OH}$, by collaborators at The Ohio State University and shipped to the Department of Entomology at the University of Nebraska-Lincoln. B. l. hirtus were reared and maintained in the greenhouse on ' 5715 ' sorghum grown in $15-\mathrm{cm}$ pots containing a potting mixture of sand-soil-peatperlite in a 2:1:3:3 ratio and maintained under greenhouse conditions $\left(27 \pm 3^{\circ} \mathrm{C}\right.$ and a photoperiod of $16: 8$ [L:D] h). Plants were watered from the top every other day and fertilized weekly with a soluble 20.0: 4.4:16.6 (N-P-K) fertilizer. Before experiment initiation, chinch bugs were dislodged from plants, sifted through a 2-mm mesh screen, collected with a batterypowered aspirator, and held in small plastic cups for $24 \mathrm{~h}$.

B. insularis were collected from infested St. Augustinegrass lawns near Temple, TX, by collaborators at Texas A\&M University Blackland Research and Extension Center, shipped to the University of Nebraska-Lincoln, and reared on susceptible 'Raleigh' St. Augustinegrass by using the procedures described for B. l. hirtus. Similarly, chinch bugs were collected from greenhouse colonies and processed as described for $B$. l. hirtus.

Acquisition and Maintenance of Plant Material. The plants used in this research were maintained in a University of Nebraska-Lincoln greenhouse at $27 \pm$ $3^{\circ} \mathrm{C}$ under $400-\mathrm{W}$ high-intensity discharge lamps (metal halide) with a photoperiod of 16:8 (L:D) h. Plants were watered daily and fertilized weekly with a soluble 20.0:4.4:16.6 (20N-10P-20K) fertilizer. The potting soil contained a mixture of sand-soil-peatperlite in a 2:1:3:3 ratio.

B. occiduus-susceptible 378 and -resistant Prestige buffalograsses were obtained from research plots at the JSA Research Facility by extracting sod plugs (10.6 $\mathrm{cm}$ in diameter by $6 \mathrm{~cm}$ in depth). Plugs were potted in $15-\mathrm{cm}$ pots containing the previously described potting mixture and maintained under greenhouse conditions. These plants served as the vegetative source of buffalograss in the screening studies.

Thirty-five by $50-\mathrm{cm}$ flats of Raleigh (B. insularissusceptible), Floratam (B. insularis-resistant), and 'Amerishade' (unknown susceptibility to B. insularis) St. Augustinegrasses were acquired from Turfgrass America in Granbury, TX. Approximately 5 by $5-\mathrm{cm}$ sections were transplanted into $15-\mathrm{cm}$ pots, maintained under greenhouse conditions, and used in subsequent screening studies.
Fine fescue tillers were shipped from Rutgers University Plant Science Research Center, Freehold, NJ; potted in 15-cm pots in the greenhouse upon arrival; and maintained under previously described greenhouse conditions. Eight experimental fine fescue lines were evaluated for chinch bug resistance, including four lines enhanced with the endophyte Epichloe festucae Leuchtmann, Schardl, \& Siegel. Two chewings fescues, 1117 DL2 and 3188-1 DL2 (containing the Delaware 2 endophyte), and two strong creeping red fescues, $1171 \mathrm{RC}$ and $1139 \mathrm{RC}$ (containing the Rose City endophyte), as well as their endophyte-free counterparts 1117 E-, 3188-1 E-, $1171 \mathrm{E}-$, and $1139 \mathrm{E}-$ were evaluated. Endophyte presence was confirmed by Rutgers University Plant Science Research Center before shipping of plant material. Endophyte presence was confirmed after completion of experiments by using $0.5 \%$ Rose Bengal staining solution following the protocol of Saha et al. (1988) and also with a Phytoscreen immunoblot kit (catalog no. ENDO7973, Agrinostics, Ltd. Co., Watkinsville, GA).

B. l. leucopterus-resistant KS94 and susceptible Wheatland sorghum seed was obtained from Kansas State University, Manhattan, KS. Seeds were held in cold storage until planting.

Establishment of Experimental Plant Units. Three weeks before introduction of chinch bugs, three sorghum seeds, individual plants of the two buffalograsses, three St. Augustinegrasses, and eight fine fescues were planted in 'SC-10 Super Cell' single cell Cone-tainers $(3.8 \mathrm{~cm}$ in diameter by $21 \mathrm{~cm}$ in height, Stuewe \& Sons, Inc., Corvallis, OR). Cone-tainers were maintained under previously described greenhouse conditions. One week before chinch bug introduction, the verdure of all buffalograss, St. Augustinegrass, and fine fescue plants was removed to ensure that all plant material was of similar age. Sorghum seedlings were thinned to one plant per Cone-tainer after germination.

Introduction of Chinch Bugs. In total, 10 fourth and fifth stage chinch bugs (sex ratio undetermined) were placed on plants in Cone-tainers fitted with tubular Plexiglas cages $(4 \mathrm{~cm}$ in diameter by $30 \mathrm{~cm}$ in height). Cage tops were sealed with organdy fabric and secured with rubber bands to prevent chinch bug escape. Infestation levels were based on previously reported research (Reinert and Dudeck 1974, Wilde et al. 1987, Crocker et al. 1989, Carrière et al. 1998, Yue et al. 2000, Heng-Moss et al. 2002, Eickhoff et al. 2004), and typical field infestation levels (Heng-Moss et al. 2002).

Evaluation of Resistance. Because esthetics is the key criterion for assessing turf quality, visual ratings were used to measure the susceptibility of the plants to chinch bug feeding injury. Plant damage ratings were taken every other day by using a $1-5$ scale, where 1 is $10 \%$ or less of leaf area with reddish discoloration; 2 is 11 to $30 \%$ of leaf area with reddish discoloration; 3 is 31 to $50 \%$ of leaf area with reddish discoloration; 4 is 51 to $70 \%$ of leaf area with reddish discoloration; and 5 is $71 \%$ or more of leaf area 
with severe discoloration, thinned turf, or dead tissue (Heng-Moss et al. 2002).

Plant heights from the soil surface to the tip of the longest extended leaf also were recorded for all sorghums at the end of the experiment. These measurements, in conjunction with chinch bug damage ratings, were used to calculate the functional plant loss index (FPLI) for each plant-insect combination (Morgan et al. 1980, Panda and Heinrichs 1983): FPLI $=1-$ (height of infested plant/ height of control plant $) \times(1-$ damage rating $/ 5) \times 100$. Low FPLI values indicate plant tolerance, whereas high values signify lack of tolerance.

In all experiments, when $80 \%$ of the chinch bugsusceptible plants had damage ratings of 4 or higher, they were individually placed in Berlese funnels (Southwood 1978) to extract and count the number chinch bugs remaining on each plant. Based on the overall treatment mean of chinch bug damage, levels of resistance were assigned as follows: highly resistant (HR, chinch bug damage rating 1 ), moderately resistant (MR, chinch bug damage rating $>1$ but $<3$ ), moderately susceptible (MS, chinch bug damage rating $\geq 3$ and $<4$ ), and highly susceptible (HS, chinch bug damage rating $\geq 4$ ) (Heng-Moss et al. 2002).

Characterization of Chinch Bug-Resistant Turfgrasses. St. Augustinegrass Resistance to B. insularis. The St. Augustinegrass 'Amerishade' was screened for resistance to $B$. insularis from 1 September to $15 \mathrm{Oc}-$ tober 2003. Raleigh and Floratam served as known susceptible and resistant checks, respectively. The experimental design was a completely randomized design with six replications per treatment.

Fine Fescue Resistance to B. l. hirtus. Eight fine fescue lines (3188-1 DL2, 3188-1 E-, 1117 DL2, 1117 E-, $1139 \mathrm{RC}, 1139 \mathrm{E}-, 1171 \mathrm{RC}$, and $1171 \mathrm{E}-$ ) were screened and compared for resistance to $B$. l. hirtus in a completely randomized design with six replications per treatment. The experiment was conducted using second and first generation chinch bugs from 1 September to 13 September 2002 (study 1) and from 4 July to 13 July 2003 (study 2 ), respectively.

A choice study also was also conducted to determine B. l. hirtus preference for the endophyte-free and -enhanced strong creeping red fescues $1171 \mathrm{RC}, 1171$ E-, 1139 RC, and 1139 E-. The experimental design was a randomized complete block design with six replications per treatment. Individual tillers of each grass were placed in vials of water and sealed with paraffin wax (Gulf Wax, Royal Oak Sales, Inc., Roswell, GA) heated to $63 \pm 2^{\circ} \mathrm{C}$. The wax was allowed to cool and vials were then randomly placed in one of four equally spaced $1.7-\mathrm{cm}$-diameter holes that were cut in circular arenas. The choice study was conducted in a growth chamber maintained at $28 \pm 2^{\circ} \mathrm{C}$ under 24 -h lighting. Fifteen adult chinch bugs were placed in the center of each arena, and the number of chinch bugs on each grass was recorded $1,2,4,8,18,24,48$, and $72 \mathrm{~h}$ after introduction of chinch bugs.

Fine Fescue Resistance to B. occiduus. Fine fescues with unknown levels of resistance to $B$. l. hirtus also were screened for resistance to B. occiduus. The ex- perimental design was a completely randomized design with six replications per treatment. The four experimental lines screened were $1117 \mathrm{E}-, 1117$ DL2, 1171 E-, and 1171 RC. Buffalograss 378 and Prestige were used as B. occiduus-susceptible and -resistant checks, respectively. The experiment was conducted with second and first generation chinch bugs from 1 September to 13 September 2002 (study 1) and 4 July to 13 July 2003 (study 2), respectively.

Characterization of Multiple Chinch Bug Resistance. Selected turfgrasses and sorghum were evaluated for resistance to multiple chinch bug species. These studies were conceived based on the documented potential of chinch bugs to use multiple plant hosts and on the extensive overlap of these plant hosts and the geographic distributions of the four chinch bug species.

St. Augustinegrass Resistance to B. occiduus. Floratam (B. insularis-resistant), Raleigh (B. insularis-susceptible), and Amerishade (resistance unknown) St. Augustinegrasses were screened for resistance to $B$. occiduus from 1 September to 15 October 2002. Buffalograss 378 and Prestige were used as known $B$. occiduus-susceptible and -resistant checks, respectively. The experimental design was a completely randomized design with six replications per treatment.

Buffalograss Resistance to B. 1. leucopterus. B. occiduus-susceptible 378 and -resistant Prestige buffalograsses were evaluated for resistance to B. l. leucopterus in a completely randomized design with 10 replications per treatment. B. occiduus also was introduced onto Cone-tainers of 378 and Prestige, which served as known susceptible and resistant checks, respectively. The treatment design was a 2 by 2 factorial (two chinch bug species and two buffalograss cultivars). The study was conducted with first and second generation chinch bugs from 9 to 21 July (study 1 ) and from 31 August to 12 September 2002 (study 2), respectively.

Sorghum Resistance to B. 1. leucopterus and B. occiduus. B. l. leucopterus-susceptible and-resistant sorghums (Wheatland and KS94, respectively) were evaluated for resistance to first and second generation B. occiduus from 9 to 29 July (study 1 ) and from 31 August to 27 September 2002 (study 2). B. l. leucopterus also were introduced onto Cone-tainers of Wheatland and KS94, which served as known susceptible and resistant checks, respectively. The experimental design was a completely randomized design with 10 replications per treatment. The treatment design was a 2 by 2 factorial (two chinch bug species and two sorghums).

Buffalograss Resistance to B. insularis and B. 1. hirtus. B. occiduus-resistant and -susceptible buffalograsses were evaluated for resistance to $B$. $l$. hirtus and $B$. insularis from 4 July to 15 July 2003 in a completely randomized design with six replications per treatment. B. occiduus also was introduced onto Cone-tainers of 378 and Prestige, which served as known susceptible and resistant checks, respectively. The treatment design was a 3 by 2 factorial (three chinch bug species and two buffalograss cultivars). 
Table 1. St. Augustinegrass resistance to B. insularis and B. occiduus

\begin{tabular}{|c|c|c|c|c|c|c|}
\hline \multirow{2}{*}{$\begin{array}{c}\text { Plant } \\
\text { selection }\end{array}$} & \multicolumn{3}{|c|}{ B. insularis } & \multicolumn{3}{|c|}{ B. occiduus } \\
\hline & Mean damage $^{a}$ & Mean no. $\mathrm{CB}^{b}$ & Resistance rating $^{c}$ & Mean damage $^{d}$ & Mean no. $\mathrm{CB}^{e}$ & Resistance rating \\
\hline Prestige & - & - & - & $5.0 \mathrm{a}$ & $0.0 \mathrm{c}$ & HS \\
\hline 378 & - & - & - & $4.5 \mathrm{a}$ & $0.2 \mathrm{c}$ & HS \\
\hline Amerishade & $3.3 \mathrm{a}$ & $48.8 b$ & MS & $1.0 \mathrm{~b}$ & $2.7 \mathrm{ab}$ & $\mathrm{HR}$ \\
\hline Raleigh & $2.7 \mathrm{a}$ & $150.7 \mathrm{a}$ & MR & $1.0 \mathrm{~b}$ & $4.2 \mathrm{a}$ & $\mathrm{HR}$ \\
\hline Floratam & $1.3 \mathrm{a}$ & $1.5 \mathrm{~b}$ & MR & $1.0 \mathrm{~b}$ & $0.8 \mathrm{bc}$ & HR \\
\hline
\end{tabular}

Means within the same column followed by the same letter are not significantly different $(P>0.05$, LSD test).

${ }^{a}$ Chinch bug (CB) damage rating $1-5$ scale, with 1 as no damage; $\mathrm{SE}=0.6$.

${ }^{b}$ Mean number of chinch bugs per Cone-tainer $45 \mathrm{~d}$ after chinch bug introduction; $\mathrm{SE}=22.2$.

${ }^{c}$ HR, highly resistant; MR, moderately resistant; MS, moderately susceptible; and HS, highly susceptible (Heng-Moss et al. 2002).

${ }^{d} \mathrm{SE}=0.2$.

${ }^{e} \mathrm{SE}=1.1$.

Statistical Analysis. Data were analyzed using mixed model analysis (PROC MIXED, SAS Institute 1999) to detect differences in chinch bug damage and number of chinch bugs at harvest. When appropriate, means were separated using Fisher's least significant difference (LSD) procedure. Interaction effects with $P$ values less than or equal to 0.10 were considered significant, and main and simple effects with $P$ values less than or equal to 0.05 were considered significant.

\section{Results and Discussion}

Characterization of Chinch Bug-Resistant Turfgrasses. St. Augustinegrass Resistance to B. insularis. Mixed model analyses detected no significant differences in chinch bug damage caused by $B$. insularis on the three different St. Augustinegrasses $(F=2.59 ; \mathrm{df}=$ $2,15 ; P=0.11)$. Amerishade and Raleigh had mean damage ratings of $3.3 \pm 0.8$ and $2.7 \pm 0.8$, respectively, whereas Floratam, the known resistant check, had a mean damage rating of $1.3 \pm 0.2$ (Table 1 ).

Although the mean damage ratings were not significantly different, significant differences were detected in the number of chinch bugs remaining on the St. Augustinegrasses at the time of harvest, $45 \mathrm{~d}$ after experiment initiation $(F=11.80 \mathrm{df}=2,15 ; P=$ $0.0008)$. At harvest, the mean number of chinch bugs on Raleigh (150.7 \pm 35.2$)$ was significantly greater than the number of chinch bugs on Amerishade $(48.8 \pm 15.4)$ and Floratam $(1.5 \pm 0.9)$. B. insularis had high reproduction on both Raleigh and Amerishade but did not reproduce. Instead, it declined in numbers on Floratam. Previous studies have shown Floratam to be antibiotic to B. insularis (Reinert and Dudeck 1974, Crocker et al. 1989). Busey and Zaenker (1992) suggested this resistance may be because of the presence of antifeedants.

The larger numbers of chinch bugs present after $45 \mathrm{~d}$ suggests that the reproductive capability of $B$. insularis is much greater on Raleigh and Amerishade than on Floratam. These susceptible plants with their elevated chinch bug numbers would have likely shown increasing chinch bug damage had the experiment continued. Although B. insularis biotypes that have the ability to severely damage Floratam have developed in parts of Florida, Floratam was moder- ately to highly resistant to the chinch bugs (obtained from Texas) used in this study. The results presented here concur with those of Reinert and Dudeck (1974) and Crocker et al. (1989) who observed similar trends in chinch bug damage and numbers on Floratam.

Fine Fescue Resistance to B. 1. hirtus. Mixed model analyses detected significant differences in chinch bug damage by $B$. l. hirtus to the fine fescues evaluated in study $1(F=3.76 ; \mathrm{df}=7,40 ; P=0.0032)$, whereas no significant differences were detected in study $2(F=$ $2.02 ; \mathrm{df}=7,40 ; P=0.08$ ). In study 1 , six of eight fine fescues were moderately to highly susceptible to $B$. $l$. hirtus, whereas two grasses (3188-1 E- and 1139 RC) were moderately resistant (data not shown). However, all grasses were moderately to highly susceptible in study 2 (data not shown). In addition, no differences in the number of chinch bugs remaining at the end of either study were detected (data not shown). The differences in chinch bug damage between the studies may be because of differences between first and second generation chinch bugs or plant vigor. Furthermore, subsequent endophyte assays documented endophyte presence in all fine fescues and documented high infection rates among 1139 RC, 1171 RC, 3188-1 DL2, and 1117 DL2. In addition, the "endophyte-free" chewings fescues $1117 \mathrm{E}$ - and 3188-1 Ehad endophyte infection rates of $\approx 50$ and $20 \%$, respectively. In contrast, the strong creeping red fescues $1171 \mathrm{E}$ - and $1139 \mathrm{E}$ - had endophyte infection rates of $<5 \%$.

In the choice study conducted with the strong creeping red fescues, mixed model analysis detected significant differences among $1139 \mathrm{E}$ - and $1139 \mathrm{RC}$, $1171 \mathrm{RC}$ and $1171 \mathrm{E}-(F=4.78 ; \mathrm{df}=3,160 ; P=0.0032)$ for numbers of chinch bugs on the plants 1 and $2 \mathrm{~h}$ postinfestation. Fewer chinch bugs were observed on $1139 \mathrm{E}$ - than any of the other three grasses. No significant differences were detected at $4,8,18,24,48$, or $72 \mathrm{~h}$. Significant differences in chinch bug numbers also were detected among the eight evaluation times $(F=5.95 ; \mathrm{df}=7,160 ; P<0.0001)$. In general, the number of chinch bugs on the plants decreased over time, which may have been a result of decreased plant quality, chinch bug vigor, or a combination. In summary, B. l. hirtus showed no preference toward the endophyte-free grasses (1171 E- and $1139 \mathrm{E}-$ ). 
In general, grasses enhanced with endophytes exhibit some level of chinch bug resistance (Saha et al. 1987, Mathias et al. 1990, Carrière et al. 1998, Richmond and Shetlar 2000, Yue et al. 2000). Yue et al. (2000) evaluated strong creeping red and chewings fescues for alkaloid concentrations, chinch bug survival, and chinch bug preference and found varying levels in alkaloid concentrations. However, the endophyte-enhanced plants generally decreased chinch bug survival and were avoided by chinch bugs when given a choice between endophyte-free and -enhanced plants. Although no preference toward the endophyte-free plants was exhibited by chinch bugs in our studies, the overall declining vigor of the chinch bugs over time may have resulted in less feeding and thus decreased numbers of chinch bugs observed on the plants.

The lack of difference in the number of chinch bugs surviving on endophyte-free or -enhanced grasses may have resulted because the plants were severely damaged and were no longer suitable hosts. Furthermore, it has been documented that genetic resistance in fine fescues is variable and that the presence of endophytes is not necessarily associated with enhanced insect resistance (Breen 1994). In fact, Breen (1993) has shown endophyte-infected plants can be more susceptible to the southern armyworm, Spodoptera eridania (Stoll), than their endophyte-free counterpart. Various factors such as temperature, drought stress, soil fertility, endophyte concentration within the plant, plant genotype, and host-endophyte interactions can all affect the allelochemical concentration within the plant (Breen 1992, 1994). Unfortunately, most research conducted on endophyte-enhanced resistance to insects has dealt with Neotyphodium endophytes, whereas those plants used in our studies were in the genus Epichloe. Although similarities exist between these two endophyte genera (e.g., alkaloid toxicity and antifeedant activity), there also may be important differences with respect to the environmental conditions that enhance their effects on chinch bug feeding behavior.

Fine Fescue Resistance to B. occiduus. In study 1, mixed model analysis detected significant differences in B. occiduus damage on the two plant species evaluated $(F=21.99 ; \mathrm{df}=5,30 ; P<0.0001)$. All fine fescues were moderately to highly resistant to $B . o c$ ciduus, whereas 378 and Prestige buffalograsses were highly susceptible and moderately resistant, respectively (Table 2 ). Although no significant differences in chinch bug damage were detected in study $2(F=2.31$; $\mathrm{df}=5,30 ; P=0.07), 378$ buffalograss and $1117 \mathrm{E}$ - fine fescue had the most damage, whereas Prestige buffalograss had the least damage. In general, all fine fescues were moderately to highly resistant to $B$. occiduus, whereas the same grasses were moderately to highly susceptible to $B$. l. hirtus.

The results of this study are similar to those reported by Breen (1993), who found varying levels of resistance in Neotyphodium-infected grasses to fall armyworm, Spodoptera frugiperda (J.E. Smith), and southern armyworm. The resistance induced by the
Table 2. Fine fescue resistance to $\boldsymbol{B}$. occiduus

\begin{tabular}{lccl}
\hline \multirow{2}{*}{$\begin{array}{c}\text { Plant } \\
\text { selection }\end{array}$} & \multicolumn{2}{c}{ Mean damage $^{a}$} & \multicolumn{1}{c}{$\begin{array}{c}\text { Resistance } \\
\text { rating }^{b}\end{array}$} \\
\cline { 2 - 3 } & ${\text { Study } 1^{c}}_{378}$ & ${\text { Study } 2^{d}}^{c}$ & HS-MS \\
Prestige & $4.2 \mathrm{a}$ & $2.7 \mathrm{a}$ & MR \\
$1117 \mathrm{E}-$ & $2.3 \mathrm{~b}$ & $1.3 \mathrm{~b}$ & MR \\
$1117 \mathrm{DL} 2$ & $1.5 \mathrm{c}$ & $1.5 \mathrm{ab}$ & MR \\
$1171 \mathrm{E}-$ & $1.2 \mathrm{c}$ & $2.7 \mathrm{a}$ & HR-MR \\
$1171 \mathrm{RC}$ & $1.0 \mathrm{c}$ & $1.5 \mathrm{ab}$ & HR-MR \\
\hline
\end{tabular}

Means within the same column followed by the same letter are not significantly different $(P>0.05$, LSD test).

${ }^{a}$ Chinch bug damage rating $1-5$ scale, with 1 as no damage.

${ }^{b} \mathrm{HR}$, highly resistant; MR, moderately resistant; MS, moderately susceptible; and HS, highly susceptible (Heng-Moss et al. 2002).

${ }^{c} \mathrm{SE}=0.3$.

${ }^{d} \mathrm{SE}=0.4$.

presence of endophytes may be correlated with the specific insect-plant interactions under investigation. However, it should be stressed that the endophytefree fine fescues were moderately to highly resistant to B. occiduus, indicating that the endophyte may have had little impact and that the plant selections alone may have been unsuitable for this chinch bug. Unfortunately, the scope of this research did not take into consideration the developmental aspects of the chinch bugs, which would have permitted a better assessment of the effects of the endophytes.

Characterization of Resistance to Multiple Chinch Bug Species. St. Augustinegrass Resistance to B. occiduus. Mixed model analyses detected significant differences in chinch bug damage ratings among the warmseason turfgrasses evaluated $(F=85.00 ; \mathrm{df}=4,25 ; P<$ 0.0001). Raleigh, Amerishade, and Floratam each had a mean damage rating of 1.0 (no damage) (Table 1). By contrast, the buffalograss 378 and Prestige were highly susceptible to $B$. occiduus, having mean damage ratings of $4.5 \pm 0.5$ and $5.0 \pm 0.0$, respectively. Although Prestige is known to be resistant to B. occiduus, it can be damaged when chinch bug infestation levels exceed the plant's ability to tolerate feeding (HengMoss et al. 2002, 2003). The duration of this experiment $(45 \mathrm{~d})$ was over twice as long as previous experiments conducted by Heng-Moss et al. 2002 and likely caused an increased level of damage on the tolerant buffalograss. Also, because of the length of the experiment and severe injury to both buffalograsses, very few chinch bugs $(<0.2 \pm 0.2)$ survived on the buffalograss plants, whereas $4.2 \pm 0.7$ and $2.7 \pm 2.3$ chinch bugs remained on Raleigh and Amerishade, respectively.

The results obtained from this study are in agreement with those reported by Eickhoff et al. (2004) who observed no damage on Raleigh St. Augustinegrass when exposed to B. occiduus for $21 \mathrm{~d}$. Furthermore, the results presented here indicate that Floratam exhibits resistance to both $B$. insularis and $B$. occiduus. Raleigh and Amerishade, however, were highly resistant to $B$. occiduus, but moderately resistant (Raleigh) to moderately susceptible (Amerishade) to B. insularis. 
Table 3. Buffalo grass resistance to $B$. l. leucopterus

\begin{tabular}{llccc}
\hline \hline \multirow{2}{*}{$\begin{array}{c}\text { Plant } \\
\text { selection }\end{array}$} & $\begin{array}{c}\text { Chinch bug } \\
\text { species }\end{array}$ & \multicolumn{2}{c}{ Mean damage } & \multirow{2}{*}{$\begin{array}{c}\text { Resistance } \\
\text { rating }\end{array}$} \\
\cline { 3 - 4 } & Study $1^{c}$ & ${\text { Study } 2^{d}}^{b}$ & \\
\hline 378 & B. l. leucopterus & $3.1 \mathrm{~b}$ & $3.1 \mathrm{ab}$ & MS \\
Prestige & B. l. leucopterus & $2.7 \mathrm{~b}$ & $4.1 \mathrm{a}$ & MR-HS \\
378 & B. occiduus & $4.3 \mathrm{a}$ & $3.3 \mathrm{ab}$ & HS-MS \\
Prestige & B. occiduus & $2.7 \mathrm{~b}$ & $2.8 \mathrm{~b}$ & MR \\
\hline
\end{tabular}

Means within the same column followed by the same letter are not significantly different $(P>0.05$, LSD test).

${ }^{a}$ Chinch bug damage rating $1-5$ scale, with 1 as no damage.

${ }^{b} \mathrm{HR}$, highly resistant; MR, moderately resistant; MS, moderately susceptible; and HS, highly susceptible (Heng-Moss et al. 2002).

${ }^{c} \mathrm{SE}=0.4$.

${ }^{d} \mathrm{SE}=0.4$.

Buffalograss Resistance to B. 1. leucopterus. Mixed model analyses detected a significant interaction between chinch bug species and buffalograss cultivar with respect to damage in both studies (study 1: $F=$ 2.87; $\mathrm{df}=1,36 ; P=0.10$ and study $2: F=3.29 ; \mathrm{df}=$ $1,36 ; P=0.08)$. In study 1 , both chinch bug species caused more damage on the buffalograss 378 than Prestige (Table 3 ). However, this difference was only significant for B. occiduus $(t=3.19, \mathrm{df}=36, P=0.003)$. Although no significant differences in chinch bug damage were detected in study $2, B$. occiduus feeding caused more damage on buffalograss 378 than Prestige, whereas B. l. leucopterus caused slightly more damage on Prestige than 378. In general, both buffalograsses were moderately to highly susceptible to $B$. l. leucopterus.

Because of the geographic overlap between these two chinch bug species and their host plants, there is potential for B. l. leucopterus to infest and damage both B. occiduus-susceptible and -resistant buffalograsses. This potential is increased because of the host-switching behavior exhibited by B. l. leucopterus as well as its extensive host range. B. l. leucopterus typically move from bunch grasses in the spring to small grains and eventually to crops such as sorghum and corn. However, Lynch et al. (1987) found that when goosegrass, Eleusine indica (L.) Gaertner (the preferred host of $B$. l. leucopterus in their study), could no longer support the chinch bug population, chinch bugs moved to nearby Bermuda grass stands. Therefore, buffalograss stands located near B. l. leucopterus-infested hosts may be at increased risk of $B$. l. leucopterus infestation and damage.

Sorghum Resistance to B. occiduus. Significant interactions between chinch bug species and sorghum selections with respect to damage were detected in studies 1 and 2 (study $1: F=11.37 ; \mathrm{df}=1,36 ; P=0.002$ and study $2: F=27.51 ; \mathrm{df}=1,36 ; P<0.0001)$. In both studies, KS94 and Wheatland were moderately to highly resistant to B. occiduus, whereas KS94 was moderately resistant and Wheatland highly susceptible to B. l. leucopterus (Table 4). The presence of resistance to both chinch bug species in KS94 and lack of multiple resistance in Wheatland likely led to the significant interaction.

No significant differences in the FPLI (based on
Table 4. Sorghum resistance to $B$. occiduus

\begin{tabular}{|c|c|c|c|c|}
\hline \multirow{2}{*}{$\begin{array}{c}\text { Plant } \\
\text { selection }\end{array}$} & \multirow{2}{*}{$\begin{array}{l}\text { Chinch bug } \\
\text { species }\end{array}$} & \multicolumn{2}{|c|}{ Mean damage ${ }^{a}$} & \multirow{2}{*}{$\begin{array}{l}\text { Resistance } \\
\text { rating }^{b}\end{array}$} \\
\hline & & Study $1^{c}$ & Study $2^{d}$ & \\
\hline Wheatland & B. l. leucopterus & $4.2 \mathrm{a}$ & $4.2 \mathrm{a}$ & HS \\
\hline KS94 & B. l. leucopterus & $2.5 \mathrm{~b}$ & $2.1 \mathrm{~b}$ & MR \\
\hline Wheatland & B. occiduus & $1.6 \mathrm{c}$ & $1.3 \mathrm{c}$ & MR \\
\hline KS94 & B. occiduus & $1.1 \mathrm{c}$ & $1.0 \mathrm{c}$ & MR-HR \\
\hline
\end{tabular}

Means within the same column followed by the same letter are not significantly different $(P>0.05$, LSD test)

${ }^{a}$ Chinch bug damage rating $1-5$ scale, with 1 as no damage.

${ }^{b} \mathrm{HR}$, highly resistant; MR, moderately resistant; MS, moderately susceptible; and HS, highly susceptible (Heng-Moss et al. 2002).

${ }^{c} \mathrm{SE}=0.2$.

${ }^{d} \mathrm{SE}=0.2$.

plant height) were detected among the sorghumchinch bug combinations in study $1(F=1.09 ; \mathrm{df}=3$, $36 ; P=0.40)$. However, significant differences among the sorghum-chinch bug combinations were detected in study $2(F=3.48 ; \mathrm{df}=3,36 ; P=0.03)$ (Table 5$)$. KS94 and Wheatland infested with $B$. occiduus had mean FPLI values of 1.0 and $8.4 \pm 4.3$, respectively. However, B. l. leucopterus-infested Wheatland had a FPLI value of $34.3 \pm 14.4$, whereas the FPLI value of KS94 was $16.3 \pm 3.2$. As mentioned, a low FPLI value indicates plant tolerance. Morgan et al. (1980) reported significant differences in the FPLI values between resistant and susceptible sorghum hybrids in response to greenbug feeding. Our results compare favorably with this study and suggest that this index may be a valuable indicator of sorghum tolerance and should be included as a parameter when accessing tolerance to chinch bugs.

The results presented here confirm the presence of resistance in KS94 to both chinch bug species, whereas Wheatland only exhibited resistance to $B$. occiduus. The levels of resistance reported for the two sorghums to $B$. l. leucopterus are in agreement with previous studies (Wilde and Bramel-Cox 1991).

Buffalograss Resistance to $\mathrm{B}$. insularis and $\mathrm{B}$. 1. hirtus. A significant interaction between chinch bug species and buffalograss cultivar with respect to damage was detected using mixed model analysis $(F=6.44 ; \mathrm{df}=$ $2,30 ; P=0.005)$. Buffalograss 378 was moderately to highly susceptible to B. occiduus and B. l. hirtus, whereas Prestige was moderately resistant to $B$. oc-

Table 5. Functional plant loss indices for $B$. l. leucopterus and B. occiduus on Wheatland and KS94 sorghum

\begin{tabular}{llccc}
\hline \multirow{2}{*}{$\begin{array}{c}\text { Plant } \\
\text { selection }\end{array}$} & $\begin{array}{c}\text { Chinch bug } \\
\text { species }\end{array}$ & \multicolumn{2}{c}{ FPLI $^{a}$} & \multirow{2}{*}{$\begin{array}{c}\text { Overall } \\
\text { mean }\end{array}$} \\
\cline { 3 - 4 } & Study $1^{b}$ & ${\text { Study } 2^{c}}$ & \\
Wheatland & B. l. leucopterus & $6.6 \mathrm{a}$ & $34.3 \mathrm{a}$ & 20.45 \\
KS94 & B. l. leucopterus & $13.2 \mathrm{a}$ & $16.3 \mathrm{ab}$ & 29.5 \\
Wheatland & B. occiduus & $9.6 \mathrm{a}$ & $8.4 \mathrm{~b}$ & 9.0 \\
KS94 & B. occiduus & $4.8 \mathrm{a}$ & $1.0 \mathrm{~b}$ & 7.9 \\
\hline
\end{tabular}

Means within the same column followed by the same letter are not significantly different $(P>0.05$, LSD test)

${ }^{a}$ FPLI $=1-($ height of infested plant $/$ ht of control plant $) \times(1-$ damage rating/5) $\times 100$.

${ }^{b} \mathrm{SE}=3.7$.

${ }^{c} \mathrm{SE}=7.7$. 
Table 6. Buffalo grass resistance to B. insularis and B. l. hirtus

\begin{tabular}{lccl}
\hline $\begin{array}{c}\text { Plant } \\
\text { selection }\end{array}$ & $\begin{array}{c}\text { Chinch bug } \\
\text { species }\end{array}$ & $\begin{array}{c}\text { Mean damage } \\
\text { rating }^{a}\end{array}$ & $\begin{array}{c}\text { Resistance } \\
\text { rating }^{b}\end{array}$ \\
\hline Prestige & B. l. hirtus & $4.8 \mathrm{a}$ & $\mathrm{HS}$ \\
378 & B. l. hirtus & $4.0 \mathrm{ab}$ & $\mathrm{HS}$ \\
Prestige & B. insularis & $3.8 \mathrm{ab}$ & $\mathrm{MS} / \mathrm{HS}$ \\
378 & B. occiduus & $3.3 \mathrm{~b}$ & $\mathrm{MS}$ \\
378 & B. insularis & $2.8 \mathrm{~b}$ & $\mathrm{MR}$ \\
Prestige & B. occiduus & $1.5 \mathrm{c}$ & MR \\
\hline
\end{tabular}

Means within the same column followed by the same letter are not significantly different $(P>0.05$, LSD test $)$.

${ }^{a}$ Chinch bug damage rating $1-5$ scale, with 1 as no damage; $\mathrm{SE}=$ 0.4 .

${ }^{b} \mathrm{HR}$, highly resistant; MR, moderately resistant; MS, moderately susceptible; and HS, highly susceptible (Heng-Moss et al. 2002).

ciduus but moderately to highly susceptible to $B . l$. hirtus and B. insularis (Table 6). Interestingly, B. occiduus-susceptible 378 was moderately resistant to $B$. insularis, but with a mean damage rating of $2.8 \pm 0.3$, there may be potential for infestation and damage to occur.

In conclusion, the germplasm used in these studies exhibited varying degrees of resistance and susceptibility to the different chinch bug species. B. occiduusresistant Prestige was moderately to highly susceptible to all other chinch bug species, whereas germplasm that was susceptible to B. l. leucopterus, B. l. hirtus, and $B$. insularis (Wheatland sorghum, fine fescues, and Raleigh and Amerishade St. Augustinegrasses, respectively) was moderately to highly resistant to $B$. occiduus. Furthermore, KS94 sorghum and Floratam St. Augustinegrass exhibited resistance to both their respective chinch bug species and B. occiduus. The varying degrees of susceptibility and resistance exhibited by the grasses underscores the importance of identifying germplasm that is not only resistant to one particular chinch bug species but also resistant to other chinch bug species inhabiting nearby field and turf areas. For example, because buffalograss is adapted to various regions throughout the United States, it is likely to be planted near areas of B. insularis and B. $l$. hirtus infestations. Therefore, identifying germplasm that exhibits resistance to multiple chinch bug species will decrease the chances of an opportunistic infestation by B. insularis or B. l. hirtus.

The reason (s) for the differential responses of the grasses to the four chinch bug species remains unclear. However, differences in chinch bug mouthpart morphology and feeding behavior may be contributing to the range of host susceptibility and resistance documented among the chinch bug species. The mouthpart morphology of chinch bugs has not been investigated since Painter (1928) examined the feeding behavior of B. l. leucopterus. In addition, a comparison of chinch bug mouthparts within the Blissus complex has not been conducted. Other researchers have compared the feeding behavior of various sap-feeding insects on resistant and susceptible hosts (Calderon and Backus 1992, Kaakeh and Dutcher 1993, Ni and Quisenberry 1997) and found variations in probing locations, frequency, and duration. Similar studies on the feeding behavior of the different chinch bug species on resistant and susceptible germplasm may provide explanations for the varying degrees of susceptibility observed.

\section{Acknowledgments}

We thank Tom Eickhoff (University of Nebraska) and S. Rochefort (Laval University-Quebec) for technical assistance. We also thank Stacy Bonos (Rutgers University), John Reese (Kansas State University), and Turfgrass America for germplasm as well as David Shetlar (The Ohio State University) and Dennis Hoffman (Texas A\&M University) for providing chinch bugs not locally available. We acknowledge Gary Hein and John Foster for reviewing this manuscript. This research was supported in part by the University of Nebraska Agriculture Experiment Station Project 17-078, the United States Golf Association, and the International Turfgrass Producers. This is paper number 14999 of the journal series of the Agricultural Research Division, University of Nebraska-Lincoln.

\section{References Cited}

Baxendale, F. P., T. M. Heng-Moss, and T. P. Riordan. 1999. Blissus occiduus (Hemiptera: Lygaeidae): a chinch bug pest new to buffalograss turf. J. Econ. Entomol. 92: 11721176 .

Bird, R. D., and A. V. Mitchener. 1950. Insects of the season 1949 in Manitoba, Can. Insect Pest Rev. 28: 41.

Breen, J. P. 1992. Temperature and season effects on expression of Acremonium endophyte-enhanced resistance to Schizaphis graminum (Homoptera: Aphididae). Environ. Entomol. 21: 68-74.

Breen, J. P. 1993. Enhanced resistance to the fall armyworm (Lepidoptera: Noctuidae) in Acremonium endophyte-infested turfgrasses. J. Econ. Entomol. 86: 621-629.

Breen, J. P. 1994. Acremonium endophyte interactions with enhanced plant resistance to insects. Annu. Rev. Entomol. 39: 401-423.

Busey, P., and B. J. Center. 1987. Southern chinch bug (Hemiptera: Heteroptera: Lygaeidae) overcomes resistance in St. Augustinegrass. J. Econ. Entomol. 80: 608611.

Busey, P. 1990. Polyploid Stenotaphrum germplasm: resistance to the polyploidy damaging population southern chinch bug. Crop Sci. 30: 588-593.

Busey, P. 1993. Registration of 'FX-10' St. Augustinegrass. Crop Sci. 33: 214-215.

Busey, P. 1995. Field and laboratory resistance of St. Augustinegrass germplasm to the southern chinch bug. HortScience. 30: 1253-1255.

Busey, P., and E. I. Zaenker. 1992. Resistance bioassay from southern chinch bug (Heteroptera: Lygaeidae) excreta. J. Econ. Entomol. 85: 2032-2038.

Calderon, J. D., and E. A. Backus. 1992. Comparison of the probing behaviors of Empoasca fabae and E. kraemeri (Homoptera: Cicadellidae) on resistant and susceptible cultivars of common beans. J. Econ. Entomol. 85: 88-99.

Carrière, Y., A Bouchard, S. Bourassa, and J. Brodeur. 1998. Effect of endophyte incidence in perennial ryegrass on distribution, host-choice, and performance of the hairy chinch bug (Hemiptera: Lygaeidae). J. Econ. Entomol. 91: $324-328$.

Crocker, R. L., R. W. Toler, and C. L. Simpson. 1982. Bioassay of St. Augustinegrass lines for resistance to southern 
chinch bug (Hemiptera: Lygaeidae) and to St. Augustine decline virus. J. Econ. Entomol. 75: 515-516.

Crocker, R. L., R. W. Toler, J. B. Beard, M. C. Engelke, and J. S. Kubica-Breier. 1989. St. Augustinegrass antibiosis to southern chinch bug (Hemiptera: Lygaeidae) and to St. Augustine decline strain of Panicum mosaic virus. J. Econ. Entomol. 82: 1729-1731.

Dahms, R. G. 1948. Effect of different varieties and ages of sorghum on the biology of the chinch bug. J. Agric. Res. 76: $271-288$.

Eickhoff, T. E., F. P. Baxendale, T. M. Heng-Moss, and E. E. Blankenship. 2004. Turfgrass, crop, and weed hosts of Blissus occiduus (Hemiptera: Lygaeidae). J. Econ. Entomol. 97: 67-73.

Farstad, C. W., and Staff, A. 1951. Insects of the season in Alberta, 1950. Can. Insect Pest Rev. 29: 18.

Ferris, G. F. 1920. Insects of economic importance in the cape region of lower California, Mexico. J. Econ. Entomol. 13: 463-467.

Funk, C. R., P. M. Halisky, and R. H. Hurley. 1983. An endophytic fungus and resistance to sod webworms: association in Lolium perenne L. Biotechnology 1: 189-191.

Heng-Moss, T. M., F. P. Baxendale, T. P. Riordan, and J. E. Foster. 2002. Evaluation of buffalograss germplasm for resistance to B. occiduus (Hemiptera: Lygaeidae). J. Econ. Entomol. 95: 1054-1058.

Heng-Moss, T. M., F. P. Baxendale, T. P. Riordan, L. Young, and K. Lee. 2003. Chinch bug resistant buffalograss: an investigation of tolerance, antixenosis, and antibiosis. J. Econ. Entomol. 96: 1942-1951.

Kaakeh, W., and J. D. Dutcher. 1993. Rate of increase and probing behavior of Acyrthosiphon pisum (Homoptera: Aphididae) on preferred and nonpreferred host cover crops. Environ. Entomol. 22: 1016-1021.

Kerr, S. H. 1966. Biology of the lawn chinch bug, Blissus insularis. Fla. Entomol. 49: 9-18.

Leonard, D. E. 1966. Biosystematics of the leucopterus complex of the genus Blissus (Heteroptera: Lygaeidae). Conn. Agric. Exp. Stn. Bull. 677: 1-47.

Lynch, R. E., S. Some, I. Dicko, H. D. Wells, and W. G. Monson. 1987. Chinch bug damage to bermudagrass. J. Entomol. Sci. 22: 153-158.

Mathias, J. K., R. H. Ratcliffe, and J. L. Hellman. 1990. Association of an endophytic fungus in perennial ryegrass and resistance to the hairy chinch bug (Hemiptera: Lygaeidae). J. Econ. Entomol. 83: 1640-1645.

Mize, T. W., and G. Wilde. 1986a. New grain sorghum sources of antibiosis to the chinch bug (Heteroptera: Lygaeidae). J. Econ. Entomol. 79: 176-180.

Mize, T. W., and G. Wilde. 1986b. New resistant germplasm to the chinch bug (Heteroptera: Lygaeidae) in grain sorghum: contribution of tolerance and antixenosis as resistance mechanisms. J. Econ. Entomol. 79: 42-45.

Mize, T. W., and G. Wilde. 1986c. Reproduction of the chinch bug (Heteroptera: Lygaeidae) on new resistance sources in grain sorghum. J. Econ. Entomol. 79: 664-667.

Morgan, J., G. Wilde, and D. Johnson. 1980. Greenbug resistance in commercial sorghum hybrids in the seedling stage. J. Econ. Entomol. 73: 510-514.

Ni, X., and S. Quisenberry. 1997. Distribution of Russian wheat aphid (Homoptera: Aphididae) salivary sheaths in resistant and susceptible wheat leaves. J. Econ. Entomol. 90: $848-853$.

Painter, R. H. 1928. Notes on the injury to plant cell by chinch bug feeding. Ann. Entomol. Soc. Am. 21: 232-242.

Panda, N., and E. A. Heinrichs. 1983. Level of tolerance and antibiosis in rice varieties having moderate resistance to the brown planthopper, Nilaparvata lugens (Stål) (Hemiptera: Delphacidae). Environ. Entomol. 12: 12041214.

Reinert, J. A., and A. E. Dudeck. 1974. Southern chinch bug resistance in St. Augustinegrass. J. Econ. Entomol. 67: 275-277.

Reinert, J. A., P. A. Heller, and R. L. Crocker. 1995. Chinch bugs, pp. $38-42$. In R. L. Brandenburg and M. G. Villani [eds.], Handbook of turfgrass insect pests. Entomological Society of America, Lanham, MD

Richmond, D. S., and D. J. Shetlar. 2000. Hairy chinch bug (Hemiptera: Lygaeidae) damage, population, density, and movement in relation to the incidence of perennial ryegrass infected by Neotyphodium endophytes. J. Econ. Entomol. 93: 1167-1172.

Saha, D. C., J. M. Johnson-Cicalese, P. M. Halisky, M. I. Van Heemstra, and C. R. Funk. 1987. Occurrence and significance of endophytic fungi in the fine fescues. Plant Dis. 71: 1021-1024.

Saha, D. C., M. A. Jackson, and J. M. Johnson-Cicalese. 1988. A rapid staining method for detection of endophytic fungi in turf and forage grasses. Phytopathology 78: 237-239.

SAS Institute. 1999. SAS/STAT software: changes and enhancements through release 8.2. SAS Institute, Cary, NC.

Shetlar, D. J. 2000. Ohio State Extension fact sheet. (http.// www.ag.ohio-state.edu/ ohioline/ hyg-fact/2000/ 2503 . html).

Southwood, T.R.E. 1978. Ecological methods. Halsted, New York.

Subramanian, R. 1995. Studies on plant resistance in sorghum to the chinch bug Blissus leucopterus leucopterus (Say) (Hemiptera: Lygaeidae). Ph.D. dissertation, University of Nebraska, Lincoln, NE.

Vittum, P. J., M. G. Villani, and H. Tashiro. 1999. Turfgrass Insects of the United States and Canada, 2nd ed. Cornell University Press, Ithaca, NY.

Wilde, G. E., and P. Bramel-Cox. 1991. Recent studies on chinch bug resistance in sorghum, pp. 121-130. In Proceedings, 45th Annual Corn \& Sorghum Research Conference, 5-6 December 1990, Chicago, IL. American Seed Trade Association, Washington, DC.

Wilde, G., T. W. Mize, and M. Meehan. 1987. Rearing and screening methodologies for the chinch bug, Blissus leucopterus leucopterus, pp. 67-73. In Toward Insect Resistant Maize for the Third World: Proceedings of the International Symposium on Methodologies for Developing Host Plant Resistance to Maize Insects, 9-14 March 1987, Mexico City, Mexico. CIMMYT, Mexico.

Yue, Q., J. Johnson-Cicalese, T. J. Gianfagna, and W. A. Meyer. 2000. Alkaloid production and chinch bug resistance in endophyte-inoculated chewings and strong creeping red fescues. J. Chem. Ecol. 26: 279-292.

Received 23 April 2005; accepted 19 October 2005. 